\title{
Multiple Causes of Hyponatremia: A Case Report
}

\author{
Tijana Icin ${ }^{a, d}$ Milica Medic-Stojanoska ${ }^{a, d}$ Tatjana Ilic $^{b, d} \quad$ Vladimir Kuzmanovic $^{e}$ \\ Bojan Vukovic ${ }^{c, d}$ Ivanka Percic ${ }^{c, d}$ Branka Kovacev-Zavisic ${ }^{a, d}$ \\ Clinics of ${ }^{\mathrm{a}}$ Endocrinology, Diabetes and Metabolic Diseases and ${ }^{\mathrm{b}}$ Nephrology and Clinical Immunology, and \\ 'Emergency Center, Clinical Center of Vojvodina, Novi Sad, d Faculty of Medicine, University of Novi Sad, Novi Sad, and \\ eDepartment of Internal Medicine, General Hospital, Sremska Mitrovica, Serbia
}

\section{Significance of the Study}

- Adequate treatment of hyponatremia in our patient, with hypertonic sodium restriction and antibiotics, led to a complete recovery without consequences despite the simultaneous multiple causes of the hyponatremia.

- This report emphasizes the importance of evaluating the types and causes of hyponatremia in each patient and points out that the signs and symptoms could quickly and significantly change.

- In patients who have multiple causes of hyponatremia at the same time, it is necessary to treat all present causes.

\section{Keywords}

Hyponatremia - Acute poststreptococcal glomerulonephritis - Alcohol abuse - Energy drink abuse . Taurine

\begin{abstract}
Objective: To present a case with 4 different potential causes of hyponatremia. Clinical Presentation and Intervention: The patient presented with the following symptoms: nausea, vomiting, diarrhea, and dark urine after drinking large amounts of fluids that included alcohol and caffeine. Laboratory, microbiological, and morphological examinations revealed the existence of severe hyponatremia and acute poststreptococcal glomerulonephritis. The patient developed acute symptomatic seizures and coma. Gradual normalization of the sodium level led to a recovery of consciousness. Conclusion: Treatment with hypertonic sodium, fluid restric-
\end{abstract}

\begin{tabular}{ll}
\hline KARGER & (c) 2017 S. Karger AG, Basel \\
$\begin{array}{l}\text { E-Mail karger@karger.com } \\
\text { www.karger.com/mpp }\end{array}$ & $\begin{array}{l}\text { This is an Open Access article licensed under the terms of the } \\
\text { Creative Commons Attribution-NonCommercial 3.0 Un- } \\
\text { ported license (CC BY-NC) (www.karger.com/OA-license), } \\
\text { applicable to the online version of the article only. Distribu- } \\
\text { tion permitted for non-commercial purposes only. }\end{array}$
\end{tabular}

tion, and antibiotics led to a complete recovery. In the case of multiple causes of hyponatremia, it is necessary to treat all causes.

(c) 2017 S. Karger AG, Basel

\section{Introduction}

Hyponatremia, with a serum sodium level $<135$ $\mathrm{nmol} / \mathrm{L}$, is the most common electrolyte disorder, reported in approximately $1 \%$ of the general population, in up to $15-20 \%$ of all patients in urgent care facilities, and in up to $30 \%$ of all patients treated in intensive care units [1]. There are several forms of hyponatremia, i.e., hypervolemic, hypovolemic, euvolemic, that manifest as redistributive and pseudohyponatremia. Hyponatremia can be acute or chronic and manifest with mild or more severe symptoms such as confusion, nausea, vomiting, cardiore-

Clinic of Endocrinology, Diabetes and Metabolic Diseases, Clinical Center of Vojvodina Hajduk Veljkova 1-3 
Table 1. Biochemistry and urine laboratory test results

\begin{tabular}{|c|c|c|c|c|c|c|c|c|}
\hline & $\begin{array}{l}\text { General } \\
\text { hospital }\end{array}$ & $\begin{array}{l}\text { Emergency } \\
\text { center }\end{array}$ & Day 1 & Day 2 & Day 3 & Day 4 & Day 6 & Day 11 \\
\hline $\begin{array}{l}\text { Sodium, } \mathrm{mmol} / \mathrm{L} \\
(135-148)\end{array}$ & $<100$ & 103 & 109 & 122 & 138 & 140 & 140 & 145 \\
\hline $\begin{array}{l}\text { Potassium, } \mathrm{mmol} / \mathrm{L} \\
(3.5-5.5)\end{array}$ & 2.8 & 4.1 & 4.2 & 4.2 & 3.6 & 4.0 & 4.3 & 4.3 \\
\hline $\begin{array}{l}\mathrm{pH} \\
(7.35-7.45)\end{array}$ & 7.37 & 7.51 & I & I & 7.42 & I & I & I \\
\hline $\begin{array}{l}\text { Lactate, } \mathrm{mmol} / \mathrm{L} \\
(0.5-1.6)\end{array}$ & 11.4 & 0.99 & 1.88 & 1.04 & I & I & I & I \\
\hline $\begin{array}{l}\text { C-reactive protein, } \mathrm{mg} / \mathrm{L} \\
(0.0-5.0)\end{array}$ & 1 & 15.1 & I & I & 12.4 & & & 3.3 \\
\hline $\begin{array}{l}\overline{B U N}, \mathrm{mmol} / \mathrm{L} \\
(2.5-7.5)\end{array}$ & 14.5 & 14.8 & 14.0 & 10.9 & 6.8 & 2.9 & 3.2 & 3.8 \\
\hline $\begin{array}{l}\text { Creatinine, } \mu \mathrm{mol} / \mathrm{L} \\
(50-115)\end{array}$ & 286 & 224 & 177 & 130 & 106 & 90 & 88 & 96 \\
\hline Urine output, $\mathrm{mL} / 24 \mathrm{~h}$ & 1 & $200 \mathrm{~mL} / 6 \mathrm{~h}$ & 2,500 & 4,500 & 4,000 & 3,000 & 2,500 & 1,850 \\
\hline Red blood cells in urine & mass & mass & I & mass & 1 & mass & 1 & 16 \\
\hline Proteins in urine & ++ & ++ & I & ++ & I & + & I & + \\
\hline
\end{tabular}

Normal ranges are in parentheses. BUN, blood urea nitrogen.

spiratory distress, sleep disorders, seizures, and coma due to several factors, like diuretics, adrenal disorders, inappropriate antidiuresis, etc. [1,2]. Clinicians frequently encounter such cases in their practice but rarely are they caused by multiple factors simultaneously [1]. Hence, we report a case with 4 causes of hyponatremia that occurred simultaneously.

\section{Case Report}

A 27-year-old man, conscious and oriented, was admitted to the Regional General Hospital complaining of symptoms such as nausea, vomiting, diarrhea, a swollen face and swollen extremities, and dark colored urine, which had developed over the previous 2 days. Laboratory tests performed upon admission showed leukocytosis $\left(21.7 \times 10^{9} / \mathrm{L}\right)$ with a predominance of granulocytes, increased levels of urea and creatinine, and the presence of hypokalemia (Table 1). Biochemical urine tests showed microscopic hematuria and positive proteins, and analysis of arterial blood showed hyponatremia with a sodium level below $100 \mathrm{mmol} / \mathrm{L}$ (Table 1). Throat swabs and urine cultures were done and therapy was started, including fluid restriction and penicillin at 1.6 million units every $12 \mathrm{~h}$, along with a proton pump inhibitor and metoclopramide.

The patient developed an acute symptomatic seizure and coma (Glasgow coma score 3) and was transported to the Emergency Center of Clinical Centre of Vojvodina, Novi Sad, Serbia. Upon admission to the Emergency Center, the patient was comatose (Glasgow coma score 3) and normotensive (140/70 mm Hg), with a respiratory rate of 30 breaths/min and a heart rate of 90 beats/ min. A computed tomography scan of the abdomen, abdominal ultrasonography, and a chest X-ray, performed upon admission, did not show pathological changes. Sodium levels still indicated hyponatremia (103 $\mathrm{mmol} / \mathrm{L}$ ) and a low plasma osmolality (i.e., 247 mosm $/ \mathrm{kg}$; normal range $270-300 \mathrm{mosm} / \mathrm{kg}$ ), while the urine osmolality was relatively high (i.e., $286 \mathrm{mosm} / \mathrm{kg}$; normal range 30 $1,300 \mathrm{mosm} / \mathrm{kg}$ ). There were no signs of hypervolemia at the time of admission, and hence therapy with hypertonic sodium, fluid restriction, correction of potassium, and antibiotics was introduced. Sodium levels in blood were gradually normalized (by not more than $0.5 \mathrm{mmol} / \mathrm{L} / \mathrm{h}$ ) to avoid central pontine myelinosis and the patient gradually regained consciousness over the following 3 days (Table 1.) Hypertension was treated with angiotensin-converting enzyme inhibitors given on several occasions. Initially high levels of urea and creatinine also normalized and the patient entered the recovery phase with diuresis of $4,500 \mathrm{~mL} /$ day (Table 1).

On the fourth day, the patient was moved to the Department of Endocrinology, Diabetes and Metabolic Disorders of for additional investigations regarding to the etiology of hyponatremia. The patient regained consciousness and a thorough examination showed that he had had a sore throat and fatigue 10 days before admission to the hospital. These symptoms lasted 1 week and he attributed them to a cold. Although he was feeling unwell, he had gone to a party with his friends at the end of that week where he drank $5,000 \mathrm{~mL}$ of beer, $400-500 \mathrm{~mL}$ of liquor, and 2,000 $\mathrm{mL}$ of energy drink (containing $25 \mathrm{~mL} / 100 \mathrm{~mL}$ of caffeine and taurine, vitamins, sugar, citric acid, and caramel) during a 6 -h period. The morning after the party, he noticed that his entire face, neck, and extremities were swollen. Afterwards, he experienced nausea, repeated vomiting, diarrhea, and dark colored urine along with excessive weakness and fatigue which continued to progress. Two days after the party, the patient contacted his doctor and was hos- 
pitalized at the General Hospital Sremska Mitrovica. A throat swab culture test that was done at the Regional General Hospital revealed Streptococcus beta haemolyticus of group A and a negative anti-streptolysin $\mathrm{O}$ titer. A repeated throat swab was negative and a seroconversion of a previously negative anti-streptolysin $\mathrm{O}$ titer (anti-streptolysin O titer $400 \mathrm{IU}$ ) was seen together with a decrease in $\mathrm{C} 3$ complement components levels. Urea and creatinine levels and the daily urine volume started to normalize but proteinuria (with a sodium level of $1,800 \mathrm{mg} /$ day) with microscopic hematuria remained (Table 1). The estimated glomerular filtration rate was $102 \mathrm{~mL} / \mathrm{min} / 1.73 \mathrm{~m}^{2}$. Mild normocytic and normochromic anemia was also observed.

Based on these data, the diagnosis of acute poststreptococcal glomerulonephritis was established. The severe acute hyponatremia followed by coma was caused by excessive simultaneous consumption of fluids, alcohol and caffeine. The normal levels of glycemia, thyroid hormones (free T3, free T4), thyroid-stimulating hormone, cortisol and adrenocorticotropic hormone led to exclusion of the possibility that hypocortisolism and hypothyroidism caused hyponatremia. After 14 days the patient was discharged from the hospital and advised to take care of his hygiene and diet and to abstain from alcohol and energy drinks. One month later, laboratory findings still indicated the presence of proteinuria (sodium level $864 \mathrm{mg} /$ day).

\section{Discussion}

Adequate treatment of hyponatremia in our patient led to a complete recovery without consequences. The literature indicates that severe hyponatremia can lead to different outcomes, from complete recovery to permanent brain damage and death [1]. Gradually increasing the concentration of sodium, as was done in this case, results in a gradual but complete recovery without any complications due to too rapid an increase in serum sodium [1]. The first cause of hyponatremia in this case was acute poststreptococcal glomerulonephritis and the patient's health was endangered by 3 other potential causes of hyponatremia, including consumption of a large amount of liquids poor in sodium (5,000 $\mathrm{mL}$ of beer), intake of caffeine, and acute alcohol intoxication followed by subsequent vomiting. The so-called, "beer potomania" is known to be the cause of hyponatremia [3]. Acute alcohol intoxication can also be associated with pronounced hyponatremia $[4,5]$. Considering the facts that the patient's weight was about $95 \mathrm{~kg}$ and that he had been drinking alcohol for 6 hours, the modified Widmark formula estimates that the average alcohol level in blood was about $0.3544 \mathrm{~g} / \mathrm{dL}$ [6]. A part from the immediate effect, this amount of alcohol caused the patient's frequent vomiting and worsened his hyponatremic state, compelling him fortunately to contact his doctor. [5] Consumption of energy drinks (2,000 mL) led to an excessive caffeine intake. The caffeine content de- clared on the labels of energy drinks, (i.e., $25 \mathrm{mg} / 100 \mathrm{~mL}$ ) confirms that this drink is relatively safe when consumed in small amounts. By drinking 2,000 $\mathrm{mL}$ of this drink, the patient consumed $500 \mathrm{mg}$ of caffeine. The diuretic and natriuretic effects of caffeine at the dose consumed by the patient could solely lead to hyponatremia. The European Food Safety Authority considers consumption of $200 \mathrm{mg}$ of caffeine to be safe and has stated that certain side effects, including hyponatremia, can be caused by higher doses [7]. Pronounced hyponatremia is rarely expected in acute post-streptococcal glomerulonephritis although there are reports in the literature that acute poststreptococcal glomerulonephritis can lead to hyponatremia [8]. Although a simultaneous occurrence of 4 causes of hyponatremia in 1 patient could be considered very unusual, the fact that this patient with the stated sodium levels $\left(\mathrm{Na}^{+}<100\right.$ $\mathrm{mmol} / \mathrm{L}$ ) was conscious, oriented, communicative, and without neurological disorders should be taken as an exception. Coma and acute symptomatic seizure occurred a few hours after the level of sodium was confirmed to be below $100 \mathrm{mmol} / \mathrm{L}$. A possible explanation for the maintained state of consciousness at these sodium levels over a long period of time is chronic hyponatremia, though this would not be option in a previously healthy person as in this case. The amount of taurine that the patient ingested by drinking energy drinks might be an alternative explanation. Taurine is a cerebral membrane stabilizer and the transport of taurine to brain cells depends on sodium and chlorine [9]. It has been shown that there is a sodium/taurine symporter in the guinea pig heart which increases the efflux of both substances to the heart cells when the concentration of any of these 2 substances is increased. If a similar mechanism exists in humans, it is possible that large amounts of taurine led to maintenance of the level of sodium in the cells of the patient, thus delaying for some time the development of severe symptoms of hyponatremia, such as convulsions and coma [10].

\section{Conclusion}

This patient had 4 simultaneous causes of hyponatremia. The late onset of coma could have been due to the large amount of taurine, which resulted in higher levels of intracellular sodium.

\section{Disclosure Statement}

None.
Icin et al. 


\section{References}

1 Spasovski G, Vanholder R, Allolio B, et al: Clinical practice guideline on diagnosis and treatment of hyponatraemia. Eur J Endocrinol 2014;170:G1-G47.

2 Tzamaloukas AH, Malhotra D, Rosen BH, et al: Contemporary reviews principles of management of severe hyponatremia. J Am Heart Assoc 2013;2:1-9.

3 Liamis GL, Milionis HJ, Rizos EC, et al: Mechanisms of hyponatraemia in alcohol patients. Alcohol Alcohol 2000;35:612-616.
4 Wrenn KD, Slovis CM, Minion GE, et al: The syndrome of alcoholic ketoacidosis. Am J Med 1991;91:119-128.

5 Bustamante EA, Levy H: Severe alkalemia, hyponatremia, and diabetic ketoacidosis in an alcoholic man. Chest 1996;110:273-275.

6 Andersson A, Wiréhn AB, Ölvander C, et al: Alcohol use among university students in Sweden measured by an electronic screening instrument. BMC Public Health 2009;9:229.

7 Agostoni C, Canani RB, Fairweathe-Tait S, et al: Scientific opinion on the safety of caffeine. EFSA panel on dietetic products, nutrition and allergies (NDA). EFSA J 2015;13:4102.
8 Dreakhshan A, Hekmat VR: Acute glomerulonephritis in Southern Iran. Iran J Pediatr 2008; 18:143-148.

9 Benrabh H, Bourre JM, Lefauconnier JM: Taurine transport at the blood-brain barrier: an in vivo brain perfusion study. Brain Res 1995;692:57-65.

10 Moh'd-Saadeh S, Glenn CR, Chapman RA: Interdependence of intracellular taurine and sodium in guinea pig heart. Cardiovasc Res 1992;26:897-905. 